\title{
Europar Batasuneko Energia-testuingurua. Eraginkortasun Energetikoa Industrian
}

\author{
(Energy framework in the European Union. Energy Efficiency \\ in Industry)
}

\author{
Naiara Romero-Anton*, Koldobika Martin-Escudero, \\ Luis Alfonso del-Portillo-Valdés
}

Makina eta Motor Termikoak Saila. Bilboko Ingeniaritza Eskola (UPV/EHU)

LABURPENA: Europar Batasunak (EB) energia merkatu aldakor bati aurre egin behar dio eta, ildo horretan, «Horizon 2020» deritzon programa jarri du indarrean. Bertan, 2020ra arteko epealdia ezarri dute honako xede hauek bideratu ahal izateko: (1) kontsumitutako energiaren \% 20ak jatorri berriztagarria izan behar $\mathrm{du},(2)$ eraginkortasun energetikoa hobetu behar da energia primarioaren erabilera \% 20 murrizteko eta, azkenik, (3) 1990. urteko balioekin alderaturik, berotegi efektuko gasak \% 20 murriztu behar dira. Eraginkortasun energetikoa bideratzeko indarrean dauden «Eraginkortasun Energetiko Plana» eta «Eraginkortasun Energetiko Direktiba 2012/27/EU» definitu dira. Bestetik, aldaketa klimatikoari aurre egiteko eta emisioak murrizteko EBk aplikatutako «cap and trade» mekanismoa eta «2020 klima eta energia paketea» azaldu dira. Dena den, ikerkuntza eta garapen teknologikoak ezinbestekoak dira «Horizon 2020» xedeak betetzeko, beraz, SET-planaren jarduerak ere aztertu dira. Horrez gain, eraginkortasun energetikoak industrian dituen aukerak aztertu dira eta, adibide moduan, SPIREk bultzatutako proiektuak deskribatu dira. Azkenik, EBk 2030 eta 2050 urteetarako proposatutako helburuak eta ikerkuntza lerroak aztertu dira.

HITZ GAKOAK: Horizon 2020, eraginkortasun energetikoa, aldaketa klimatikoa, industriaren aukerak.

ABSTRACT: European Union (EU) is facing a changing energy market. In order to overcome this situation EB launched «Horizon 2020», so that, for 2020 (1) 20\% of energy consumption must come from renewable sources, (2) improve energy efficiency to reduce the amount of primary energy used by $20 \%$ compared with projected levels and (3) reduce 20\% of greenhouse gas emissions compared with 1990 levels. Energy Efficiency improvement is supported by «2011 Energy Efficiency Plan» and «Energy Efficiency Directive 2012/27/EU». Climate change and emissions are controlled by cap and trade mechanism as well as "2020 climate and energy package». Anyway, technology research and innovation are necessary to achieve «Horizon 2020» objectives; therefore, SET-pan activities are described. Besides, industry opportunities in energy efficiency are analysed, and as an example, SPIRE holding projects are examined. Finally, EU targets for 2030 and 2050 and future research lines are studied.

KEYWORDS: Horizon 2020, energy efficiency, climate change, industry opportunities.

\footnotetext{
* Harremanetan jartzeko/Corresponding author: Naiara Romero Anton. Makina eta Motor Termikoak Saila. Bilboko Ingeniaritza Eskola, UPV/EHU, Ingeniero Torres Quevedo Enparantza 1 (48013 Bilbo-Bizkaia), Euskal Herria. - naiara.romero@ehu.eus https://orcid.org/0000-0001-5044-6391.

Nola aipatu / How to cite: Romero Anton, Naiara; Martin-Escudero, Koldobika; del-Portillo-Valdés, Luis Alfonso (2019). "Europar Batasuneko Energia-testuingurua. Eraginkortasun Energetikoa Industrian»; Ekaia, 36, 2019, 191-207. (https://doi.org/10.1387/ekaia.19698).

Jasoa: 14 maiatza, 2018; Onartua: 11 urtarrila, 2019.

ISSN 0214-9001 - elSSN 2444-3255 / (c) 2019 UPV/EHU

(c) (i) (2) Obra hau Creative Commons Atribución 4.0 Internacional-en

(c) ${ }_{\text {BY }}$ SA lizentziapean dago
} 
Naiara Romero-Anton, Koldobika Martin-Escudero, Luis Alfonso del-Portillo-Valdés

\section{SARRERA}

Europar Batasuna (EB), gaur egun, aurre egiten ari zaie energia eskaera handiari, prezio aldakorrei eta energiaren horniketak eragindako asaldurei. Horretarako, teknologia berrietan, eraginkortasun energetikoan eta berriztapenean buru-belarri lanean ari da. Gainera, energia-testuingurua aztertzen denean, energia arloak ingurumenean duen eragina ere kontuan hartu beharrekoa da. Hori dela eta, EBko energia-testuinguruan hiru puntu nagusi hauek definituko dira: (1) Eraginkortasun energetikoa industrian, garraioan eta eraikinetan, (2) klima aldaketa, eta (3) ikerketa eta garapen teknologikoa. Aurreko puntu nabarmenak kontuan hartuta, 2014ko urtarrilean EBk «Horizon 2020» [1] programa jarri zuen indarrean. Programa horren barruan, EBk energiaren inguruko helburuak definitzen ditu:

1. EBk kontsumitzen duen energiaren \% 20ak jatorri berriztagarria izan behar du.

2. Eraginkortasun energetikoa hobetu behar da energia primarioaren erabilpena \% 20 murrizteko.

3. 1990. urteko emisio mailarekin alderaturik, berotegi efektuko gasen emisioa \% 20 murriztu behar da. Aldebakartasun konpromisoa Kyotorekin.

Energia berriztagarriei dagokienez, 2009/28/EC Direktiban [2] energia mota horiek erabiltzeko helburuak definitzen dira. Dena den, artikulu honetan «Horizon 2020» programako helburuetan sakonduko da soilik, zeinek industriaren eraginkortasun energetikoan erlazio zuzena baitute.

\section{ERAGINKORTASUN ENERGETIKOA}

EBko energia politikan, eraginkortasun energetikoa kontuan izan beharreko eragile nagusienetarikoa izan da beti. Gainera, 1980ko krisi ekonomikoa hasi zenetik, eraginkortasun energetikoaren ikerkuntzak industrian, garraioan eta eraikinetan izan du lehentasuna. Hori dela eta, «Horizon 2020» programako xedeei eusteko «2011 Eraginkortasun Energetiko Plana» [3] eta «Eraginkortasun Energetiko Direktiba 2012/27/EU» [4] inplementatu ditu.

2011 Eraginkortasun Energetiko Plana, planetaren baliabideak errespetatzean oinarritzen da, karbono-baxuko sistemak ahalbidetuz. EBk energia independentzia hobetzeko ahaleginak egiten ditu eta energia horniketaren segurtasuna indartzen du. Planaren funtsezko gaiak honako hauek dira: Batetik, eraikuntza arloak energia kontsumoa baxua izan behar du, sektore horrek bukaerako energia kontsumoaren \% 40a ekartzen baitu; beste- 
tik, industria ekipamendu eta azpiegitura berriak garatzeko eta erabiltzeko sustatzea, horretarako emisioen zerga-arintze salerosketa Direktiba [5] eta emisio industrialen Direktiba [6] bete behar dira; Ekolabel deritzona bultzatzea, eraginkortasun energetikoa betetzen duten produktuak sustatuz, eta ekodiseinu Direktiba [7] indartzea;azkenik, eraginkortasun energetikoa finantzatzeko, tresna finantziarioa sortzea [8].

Eraginkortasun Energetiko Direktibaren helburu nagusia estatu kide guztiak lege berberaren pean egotea da, 2020 urterako \% 20ko eraginkortasun energetikoa lortzeko. Zuzentarauak energiaren segida osoa kontuan izaten du, energiaren transformaziotik banaketa eta bukaerako kontsumora arte. Gainera, estatu kide bakoitzak Direktibaren kondizioak lege nazionalean ezarri behar ditu. Bestetik, eraginkortasun energetikoaren helburuak indartzeko, erakunde publikoek rol edo betebehar eredugarria izan behar dute, adibidez, produktu, eraikuntza eta zerbitzu efizienteak erabiliz. Hala ere, «Eraginkortasun Energetiko Direktiba 2012/27/EU» $2020 \mathrm{ko} \% 20 \mathrm{ko}$ eraginkortasun energetiko xedearen inguruan egin zenez, 2030. urterako aurreikuspenekin [9] eguneratu behar da. Hurrengo irudian (1. irudia) EBko Eraginkortasun Energetiko Direktibaren bide-orria erakusten da.

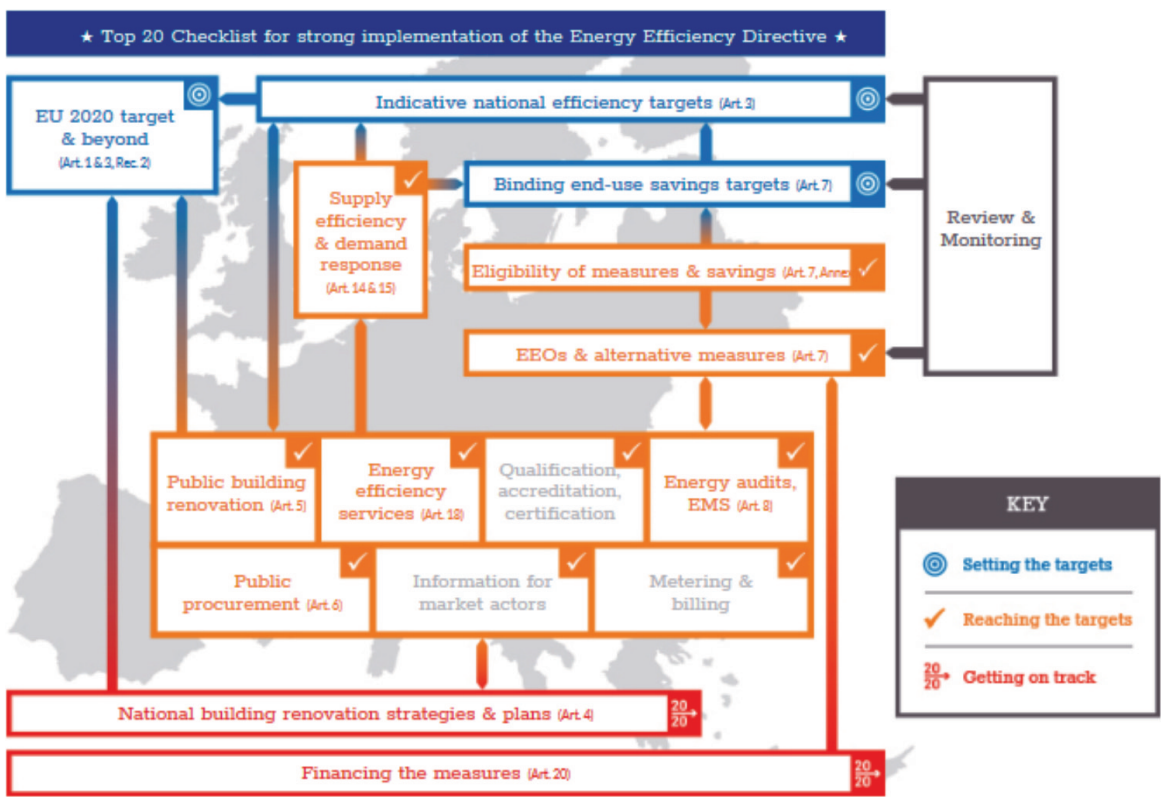

1. irudia. Eraginkortasun Energetikoaren Direktibaren bide-orria [10]. 
Naiara Romero-Anton, Koldobika Martin-Escudero, Luis Alfonso del-Portillo-Valdés

\section{ALDAKETA KLIMATIKOA}

Gure eguneroko bizitzan aldaketa klimatikoa antzematen hasi gara, eta gaur egun gizarteak daukan erronka nagusia aldaketa hori kontrolatzea da. Ingurumenarekiko eragina kontrolatzeko, erkidego internazionalak lehenengo urratsa eman du, ingurumeneko batezbesteko tenperatura $2^{\circ} \mathrm{C}$ baino gehiago ezin dela igo hitzartuz. Tenperatura gehikuntza hori klima aldaketari buruzko Pariseko konferentzian (COP21) edo Pariseko Hitzarmenean [11] adostu zen.

Aldaketa klimatikoak erlazio estua dauka energia sektorearekin, berotegi efektuko gasak baitira haren eragileak. Hori dela eta, EB gogotsu lan egiten ari da emisioak mugatzeko, eta «2020 klima eta energia paketea» [2] erreminta garatu du horretarako. Pakete horren oinarrizko hiru helburuak dira (1) 1990. urteko mailarekin alderatura, berotegi efektuko gasak \% 20 murriztea, (2) EBk kontsumitzen duen energiaren \% 20ak jatorri berriztagarria izatea eta (3) EBko eraginkortasun energetikoa \% 20 hobetzea. «2020 klima eta energia paketea»ren xedeak «Horizon 2020» programak dituenaren antzekoak dira, azken batean, bien helburua EBn energia primarioa aurreztea baita.

Berotegi efektuko gasak murrizteko EBk Emisio Salerosketa Sistema (ESS) berriztatu du, emisioei prezio bat emanez; bestetik, «cap and trade» politika jarraitu dute potentzia instalakuntzetan (20 MW baino gehiagoko potentzia termikoa duten errekuntza instalazioak eta $20 \mathrm{MW}$ baino gehiagoko potentzia elektrikoa ekoizten duten instalazioak) eta zenbait industriatan (findegi, zementu, kare, zeramika, beira, siderurgia, paper eta kartoi industriak). Dena den, 2009/29/CE Zuzentaraua [12] 2013an indarrean sartu zenez geroztik sektore berriak sartu ziren «cap and trade» eskeman, hala nola industria kimikoa, aluminio, kobre, zink eta metal ez ferrosoen industriak eta $\mathrm{CO}_{2}$ ren hartze, garraio eta biltegiratzea.

«Cap and trade» politika mekanismo bat da kostu teknologiko minimoan berotegi efektuko gasen emisioa murriztea sustatzen duena. Horretarako, mekanismoa bi kontzeptu klabetan oinarritzen da; alde batetik, emisioen isurketari muga-balio bat ezartzen zaio eta bestetik, berotegi efektuko gasak isurtzeko eskubidea transferi daiteke eragileen artean beti balio ekonomiko baten truke. Beraz, kostu minimo baten truke berotegi efektuko gasen emisioa murriztu dezaketen instalakuntzek teknologia berrietan inbertitzen dute (filtroak, tratamenduak edo/eta $\mathrm{CO}_{2}$ ren biltegiratzea). Emisio murrizketak isurpen eskubideak ahalbidetzen ditu. Eskubideen salmenta prezioa inbertsioaren kostua baino altuagoa denean, eskubideak saldu egiten dira. Bestetik, berotegi efektuko gasak murrizteko beharrezkoa den teknologiaren kostua, eskubideak erostea baino garestiagoa denean, instalakuntzak emisio eskubideak erosten ditu, «cap and trade» mekanismoari jarraituz.

Dena den, hori ez da nahikoa «Horizon 2020» programaren helburuak lortzeko, eta «Set-Plan» [13] edo «Energia Teknologia Estrategikoa» ezinbestekoa izan da horretarako. 


\section{IKERKUNTZA ETA GARAPENA TEKNOLOGIAN}

2007tik aurrera, EBko energia eta klima politikan, Set Plan ikerkuntza eta garapen teknologikoaren ardatz bihurtu da. Hala ere, 2013ko maiatzean Set-Plan indartu eta eguneratu egin zen integratutako bide-orriarekin [14]. EBko estatu kideek, beste herrialde batzuekin batera (Islandia, Norvegia, Turkia eta Suitza), karbono baxuko ikerkuntza eta garapen ekintzak koordinatzen dituzte. Nahiz eta Set-Plan teknologiaren ikerkuntzan beharrezko erreminta izan, traba pilo bati aurre egin behar dio bidean zehar, adibidez, gauzak aurrera eramateko denbora luzean itxaron behar izateari, oztopo legal eta administratiboei, energia teknologia berrietarako merkatu naturalik ez izateari edota gizarte onarpenari eta gehiegizko kostuei. Beraz, EBren papera garrantzitsua da energia teknologien ibilbidean; azken finean, herri industrializatuekin eta suspertzen ari diren ekonomiekin lehiatu behar duelako. Azkenik, erabakiak hartzeko denbora eta nazioarteko lankidetza funtsezko oinarriak dira helburua lortzeko.

Set-Planarekin jarraituz, garatu beharreko teknologien mapa ikus daiteke 2. irudian, eta bertan teknologia bakoitza inplementatzeko erronka eta lehentasuna definitzen dira:

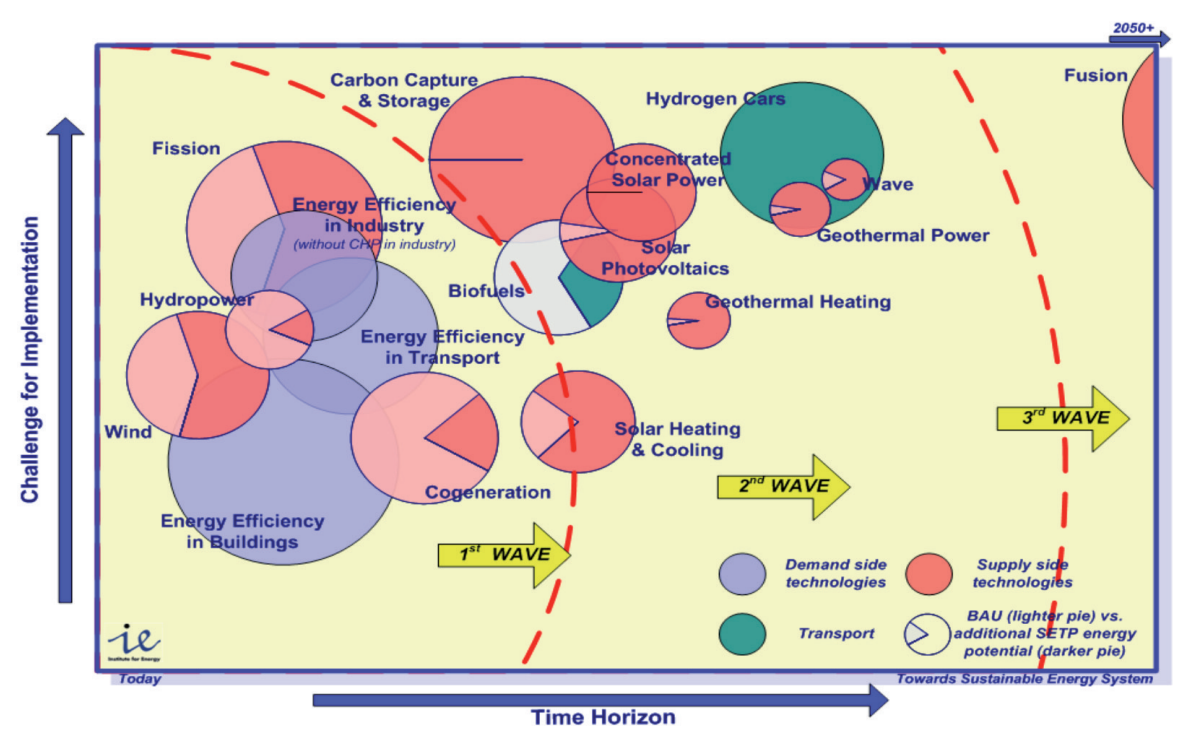

2. irudia. Set-Plan teknologia mapa [15].

Set-Plan deritzonaren arabera, 2. irudian ikusten den moduan, «X» ardatzean denbora horizontea agertzen da eta teknologien arteko lehentasuna 
Naiara Romero-Anton, Koldobika Martin-Escudero, Luis Alfonso del-Portillo-Valdés

definitzen da. Hiru olatutan banatuta dago; lehenengo olatuan berehala parte hartu beharreko sektoreak agertzen dira, horniketa instalakuntzak (gorriz) eta eskaera teknologiak (urdinez). Bigarren olatuan, bigarren mailako lehentasuna duten teknologiak agertzen dira, berriz horniketa instalakuntzak (gorriz) eta garraioak (berdez). Azkenik, hirugarren olatuan, garapen teknologiko gutxien behar duten teknologiak agertzen dira. Bestetik, «y» ardatzean teknologia bakoitza inplementatzeko erronka definitzen da. Beraz, Set-Plan teknologia maparen arabera ondoriozta dezakegunez, SetPlan-ek lehentasuna ematen dio energia berriztagarrien hornikuntza instalazioei eta eskaera teknologien eraginkortasun energetikoa hobetzeari , hau da karbonobaxuko politikan oinarritzen da.

Industriako eraginkortasun energetikoa maparen ezkerraldean agertzen da; beraz, garrantzitsua eta beharrezkoa da arlo horretan lan egiten hastea, lehen mailako lehentasuna baita. Gaur egun, Europako industriak aukera dauka teknologia eraginkor eta garbian munduko liderra izateko. Horren inguruan «Horizon 2020» eta «Europako Energia Atomiko Erkidegoa» (Euraton) [16] elkarren osagai dira industriako eraginkortasun energetikoa hobetzeko. Euraton ikerkuntza eta trebakuntza programa 5 urtean zehar dabil (2014tik 2018ra). Programa arlo nuklearrean berrikuntzak egitean oinarrituta dago, batez ere, fusioan, segurtasun nuklearrean, erradiazio babesean eta medikuntza aplikazioetan. Euraton programaz gain, beste bi erakunde ari dira ildo berean lanean: EBT (Europako Institutua Berrikuntzan eta Teknologian) [17] eta JIZ (Juntura Ikerkuntza Zentroa) [18].

\section{ERAGINKORTASUN ENERGETIKOA INDUSTRIAN}

Eraginkortasun energetikoak produktibitateari nahiz operazioari onurak ekartzen dizkie industria arloan, horrela, aurreztutako energiaren balioa 2,5 aldiz handiagoa (\% 250) izan liteke. Horrexegatik, ezinbestekoak dira manufaktura-prozesuaren diseinua, energia berreskuratzea, kontu-ikuskapena eta energia kudeaketa, industriako bero hondarrak berrerabiltzea eta instalakuntzen diseinu ezin hobea.

Eurostat-en arabera (2015eko maiatza) [19], industriaren energia kontsumoa gutxi gorabehera EBren amaierako kontsumo energetikoaren $\% 25 \mathrm{a}$ da. Balio horrek egiaztatzen du industrietan beharrezkoa dela eraginkortasun energetikoaren hobekuntza, batez ere, energia kontsumo handia, itzela duten industria aplikaziotan, adibidez, burdingintzan eta altzairugintzan, zementuan, kimikan, petrokimikan, beiragintzan eta zeramikagintzan. Bestalde, industriako eraginkortasun energetikoa hobetzeko, arreta handia eman behar zaio bero hondarra berreskuratzeari, eta hori egiteko aukerak, adibidez, potentzia zentraletan eta parke industrialetan sor- 
tzen dira. Industriak energia aurrezteko dituen aukerak SPIRE (Sustainable Process Industry thought Resource and Energy Efficiency) [20] elkarteak lantzen ditu, eta LEIT ere (Leadership in Enabling and Industrial Technologies) [21], Horizon 2020 programaren parte baita, laguntzen du zeregin horretan.

SPIRE dugu Partzuergo Publiko-Pribatua kudeatzeaz eta inplementatzeaz arduratzen den Europako Elkartea. Industria prozesu berritzaileak eta zementu, zeramika, kimika, ingeniaritza, mineralak, material ez-ferritikoak, altzairu eta ur sektoreak ordezkatzen ditu.

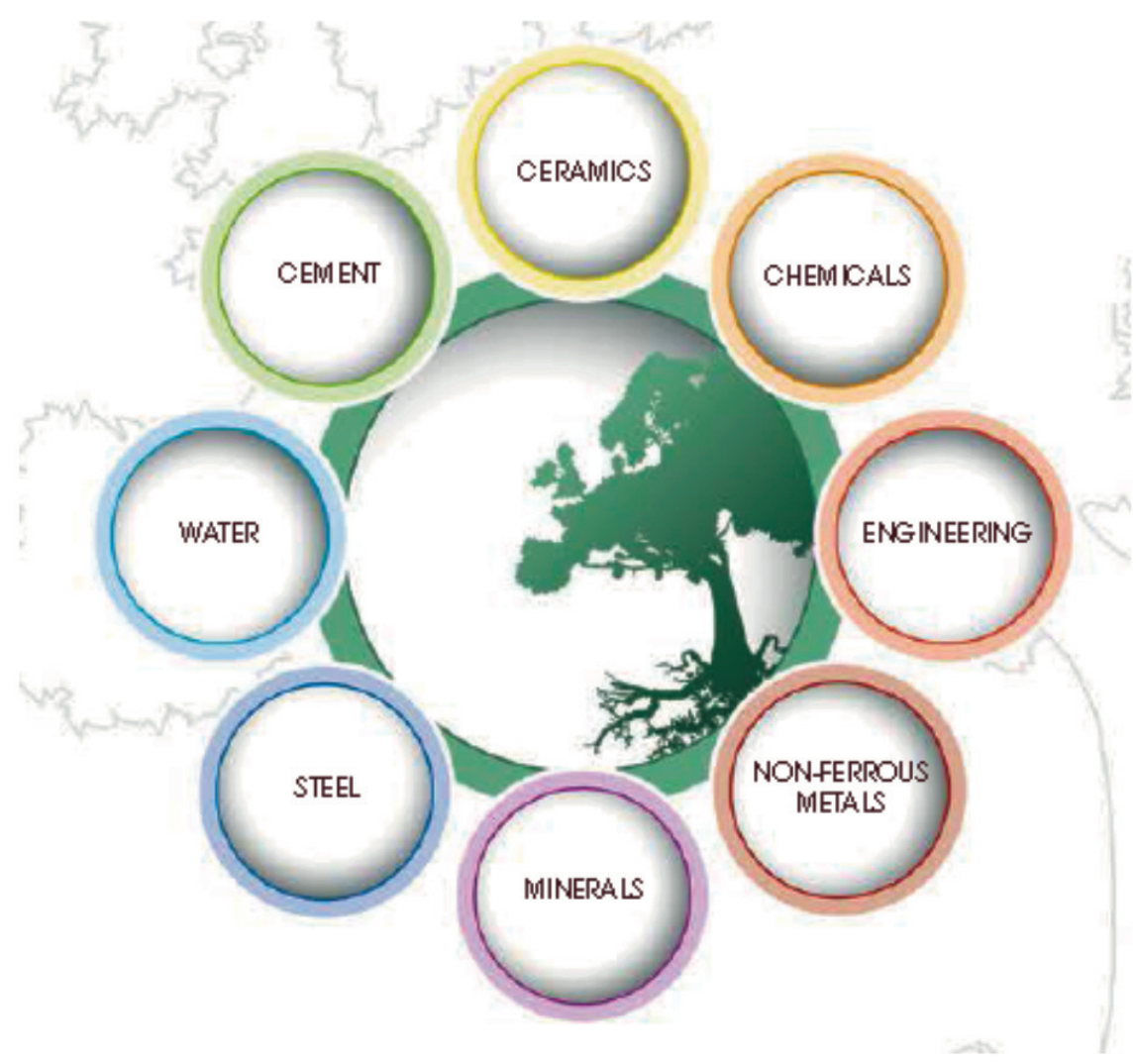

3. irudia. SPIRE ikuspegi globala [20].

SPIREk Europako erronkarekin batera lan egiten du, hau da, industriako energia eraginkortasunaren hobekuntzan eta garapenean jo eta ke dabil lanean. Beraz, energia berreskuratzearen inguruan buru-belarri ari diren zenbait proiektu aurkeztuko ditugu hurrena. 
Naiara Romero-Anton, Koldobika Martin-Escudero, Luis Alfonso del-Portillo-Valdés

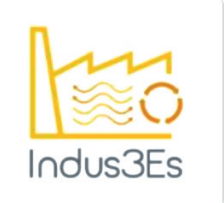

Indus3Es (Industrial Energy and Environment Efficiency) [22]. Proiektu honen helburua Absortzio Bero Transformadore (ABT) berritzaile bat garatzea da, zeinak industriak isurtzen duen tenperatura baxuko $\left(<130^{\circ} \mathrm{C}\right)$ bero hondakina berreskuratzen baitu, hain $\mathrm{zu}-$ zen ere. Proiektuaren emaitza da berreskuratutako tenperatura baxuko beroa \% 50 handiagotzen duen eta ekonomikoki bideragarria den soluzio bat lortzea. Horretarako, lau ABT konfigurazio garatu dira, bi presio altuetarako eta beste bi presio baxuetarako. Bestetik, $\mathrm{Cu}$ hodien korrosioa hobetzeko $\mathrm{SiO}_{2}$ eta epoxyn oinarritutako geruzak egokiak direla ondorioztatu dute. Azkenik, garatutako ABT konfigurazioak erabiliz, energia instalakuntzen eraginkortasun energetikoa hobetuko da energia primarioaren kontsumoa murriztuz. Proiektu horretan parte hartzen duten kontsorzioak dira Fundacion Tecnalia, TU Berlin, Technion, BS Nova Apparatebau, Aiguasol, Tüpras, Repsol, Fertinagro Biotech, Circe eta PNO.

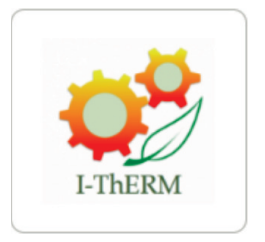

I-ThERM (Thermal Energy Recovery Conversion and Management) [23]. Proiektu honek industriako osagai anitzetik $70^{\circ} \mathrm{C}-1.000^{\circ} \mathrm{C}$ tenperatura tarteko beroa berreskuratzea du helburu. Horretarako, beroa berreskuratzeko bi-faseko bero trukagailuak ikertu, diseinatu, eraiki eta erakusten ditu. Tenperatura altuko gainazal erradiatzaileetatik beroa berreskuratuko da Hodi Bero Lau Sis-

tema (HBLS) erabiliz. Gainerako tenperaturen hondar beroa Hodi Bero Kondentsazio Ekonomizadoreek (HBKE) berreskuratuko dute. Ahalik eta hondar bero gehiena berreskuratzeko, ihes gasak ihintz puntu azpitik hoztea da helburu. Horretarako, hodiak korrosiotik babestuko dituzten geruza berritzaileak garatuko dira proiektuan zehar. Berreskuratutako hondar beroaz berriak diren bi ziklo termodinamiko potentzia elektrikoa sortzea espero da. Tenperatura baxuko aplikazioetan $\left(70-200^{\circ} \mathrm{C}\right)$ Hiru-aldeko Flash Zikloa (HFZ) erabiliko da. Tenperatura ertain eta altuko aplikazioetan karbono dioxidoa egoera gainkritikoan $\left(\mathrm{sCO}_{2}\right)$ duen Brayton zikloa erabiliko da. Beraz, espero den emaitza da teknologia berriak aplikagarriak direla frogatzea, batez ere altzairu eta jariakinen manufaktura instalazioetan. Horren ondorioz, \% 15eko energia primarioa aurreztea espero da. Gainera, hondar beroaz sortutako elektrizitateak galdaraz edo elektrizitate saretik lortutako elektrizitatea ordezkatuko du, berotegi efektuko gasen emisioa murriztuz. Proiektu honetan parte hartu duten enpresak dira Brunel University London, Spirax Sarco, TATA Steel, Synesis, Enogia, E4-Experts $\mathrm{GmbH}$, ArcelorMittal Espana, Econotherm, Avanzare, Cyprus University of Technology, CETRI, Technological Educational Institute of Sterea Ellada eta ARLUY. 
Europar Batasuneko Energia-testuingurua. Eraginkortasun Energetikoa Industrian

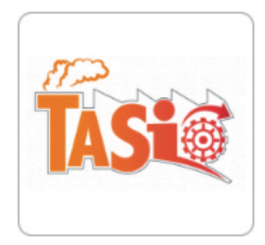

TASIO (Waste Heat Recovery for Power Valorisation with Organic Rankine Cycle (ORC) Technology in energy Intensive Industries) [24]. Proiektu hau energetikoki intentsibo diren prozesuetatik hondar beroa berreskuratzeko soluzio baten bila dabil. Horretarako, fluido organikoarekin zuzenean lan egingo duten bero trukagailu bereziak diseinatzen ari dira. Berreskuratutako hondar beroaz potentzia elektrikoa sortuko da, sarean saltzeko edo industriako prozesuan erabiltzeko. Ingurune korrosibo eta tenperatura altutan lan egiten denez, material berritzaileak garatuko dira. Instalakuntza DEMO baten bitartez balioztatuko da. Espero den emaitza nagusia tekniko-ekonomikoki industrian aplikatzeko proiektu bideragarria izatea da. Horretarako, hasierako inbertsioa txikiagotzea espero da bero trukagailuaren konplexutasuna murriztuz eta errendimendua hobetuz. Gainera, industriaren lehiakortasuna hobetuko da, saretik hartzen duen elektrizitate potentzia murriztuko baita. Azkenik, energia primarioaren kontsumoa murriztuko da, $\mathrm{CO}_{2}$ emisioak murriztuz. Proiektu honetan parte hartu duten enpresen partzuergoa hurrengoa da: TECNALIA Research \& Innovation, Turboden, RINA, Geonardo, Sidenor, Cementirossi eta Vidrala.

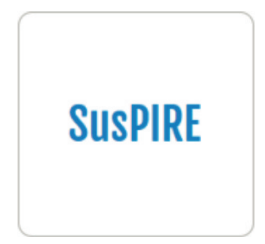

SusPIRE (Sustainable Productio of Industrial Recovered Energy) [25]. Energia disipatiboa eta biltegiratze teknologia erabiltzen dute proiektu honetan. Gainera, intentsiboak diren industrietan korronte hondar beroa berreskuratzen dute. Proiektu honen ezaugarriak Bero Transferentzia Fluido berri bat (BTF) eta Fase Aldaketa duten Materialak (FAM) erabiltzean dautza bero trukagailu eraginkorren diseinuan. Gainera bi zulo sakonetan, tenperatura baxuko $\left(30-50^{\circ} \mathrm{C}\right)$ eta ertaineko $\left(50-80^{\circ} \mathrm{C}\right)$ hondar beroa metatuko da. Proiektuan lortu diren emaitzak dira: hegalez hornitutako bero trukagailu berezi baten bitartez tximiniatik datozen tenperatura altuko $\left(600^{\circ} \mathrm{C}\right)$ errekuntza gasen hondar beroa aprobetxatzea; tenperatura baxuko aplikazioetan $\left(165^{\circ} \mathrm{C}\right)$ hondar beroa berreskuratzeko eta metatzeko bero trukagailuak FAMkin diseinatu dira eta zuloetan biltegiratutako energiak tenperatura baxuko energia eskaera (bulegoen aire-girotze sistema) hornitzea. Azkenik, hondar beroaren aprobetxamenduari esker energia primarioaren kontsumoa \% 20.29 murriztuko da. Proiektu honetan parte hartu duten enpresak honako hauek dira: Dow Corning Europe, Bayerisches Zentrum fur Angewandte Energieforschung, Tecnodelta, Telur Geotermia y Agua, Qpunkt, UAB Modernios E-Technologijos, PCB, IK4-Tekniker eta IK4Azterlan. 
Naiara Romero-Anton, Koldobika Martin-Escudero, Luis Alfonso del-Portillo-Valdés

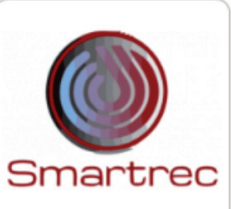

Smartrec (Developing standard modularised solution for flexible and adaptative integration of heat recovery and thermal storage capable of recovery and management of waste heat) [26]. Proiektu honetan ere, hondar beroa berreskuratzen da, baina erabilitako teknologia desberdina da, beroa biltzeko urtutako gatzak erabiltzen dira, eta bero hodiak bero trukagailu moduan. Teknologia berritzaile horiek aplikatzean espero da gas naturala aurreztea, $\mathrm{CO}_{2}$ emisioak murriztea eta petrolioa aurreztea. Urte hauetan zehar laborategi eskalako bi instalakuntzen muntaia bukatu da eta probatzeko prest daude; gainera, benetako neurriko prototipo industriala eraikitzen bukatu dute. Proiektuaren parte hartzaileak TWI, CEA, Econotherm, Spike Renewables, Innora, Ainoouchaou Pliroforiki, FLOWPHYS, Technovative Solutions eta ITC dira.

Bestetik, labeen diseinua eta haien eraginkortasun energetikoa hobetzeko, honako proiektu hauek daude abian.

VULKANO (Novel integrated refurbishment solution as a key path toward creating eco-effizient and competitive furnace) [27]. Proiektu honen helburua da gas naturala erabiltzen duten labe industrialen energia eraginkortasuna \% 20 hobetzea eta erregai kontsumoa \% 27 aurreztea; irtenbide bat diseinatuz, inplementatuz eta balioztatuz. Horretarako, materiale erregogor berriak erabiliko dira, energia berreskuratzeko tenperatura altuko FAM erabiliko da, bi-tiro (co-firing) eta integratutako kontrol sistemak erabiliko dira. Alde batetik, tenperatura altuagoetan lan egingo eta bizitza luzeagoa izango duen material erregogorrak diseinatzea espero da. Material horien bitartez prozesuaren energia eraginkortasuna \% 5 hobetuko da. Bestetik, FAM erabiliz energia berreskuratuko da eta co-firing inplementazioaren bitartez (syngas) gas naturalaren portzentaje altu bat ordezkatzen denez, energia primarioaren kontsumo murriztea espero da. Proiektu honetan buru-belarri lan egiten ari diren enpresak dira PCM, Fives, Circe, Tecnalia, Torrecid, Cidaut, Fraunhofer, Ria, Bosio, Valji eta Instytut Energetyki.

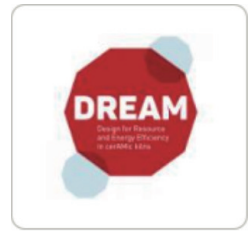

DREAM (Design for Resource and Energy efficiency in ceramic kilns) [28]. Zeramika labe industrialen energia kontsumoa optimizatzea, emisioak murriztea eta funtzionamendu kostua txikiagotzea du helburu. Horretarako, labearen kontrol sistema berrituko da, material erregogorrak eta emisio sistemak landuko dira eta bero hodiak eta Bero Potentzia Konbinatuak (BPK) erabiliko dira. Proiektu honen bitartez espero den emaitza labearen energia eraginkortasuna hobetzea da (BPK integratuz errekuntza fasean eta bero hodien 
bitartez hondar beroa berreskuratuz), baita ere garatutako metodologia eta ekipoak zeramika labeetan inplementatu daitezkeela erakustea. Parte hartzen duten erakundeak dira Brunel University London, CRIT, Econotherm, FGF, ITC, Keraben Grupo, MIRAGE, RATH, SACM, Synesis eta Università di Modena e Reggio.

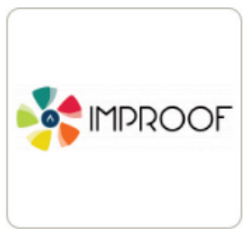

IMPROOF [29]. Proiektu honetan espero diren emaitzak dira emisioak \% 25 murriztea eta «craking» labeen energia eraginkortasuna \% 20 hobetzea. . Horretarako, hoditerian aluminio aleazio berriak erabiliko dira, horri esker craking labeetan sartzen den energia murriztuko da. Bestetik, bero transferentzia areagotzeko, emisibitate altuko geruzak erabiliko dira. Horien bitartez erradiaziozko bero transferentzia abiadura handiagotuko da eta prozesuko tenperatura lortuko da erregaiaren kontsumoa murriztuz. Ondorioz, gas erregaiaren kontsumoa eta $\mathrm{CO}_{2}$ emisioak \% 10-15 murriztuko dira. Azkenik, errekuntza eraginkortasuna hobetzeko eta $\mathrm{NO}_{x}$ eta $\mathrm{CO}$ emisioak murrizteko, biogas eta bio-oil erregaiak erabiliko dira. Proiektu honetan parte hartzen duten enpresen kontsorzioa honako hauek osatzen dute: AVGI, Ayming, CERFACS, CNRS-LRGP, CRESS, DOW Benelux B.V., Ghent University, John Zink, POLIMI, Schmidt+Clemens eta Technip Benelux.

Energia Eraginkortasun Kudeaketan, berriz, proiektu hauek aipa daitezke:

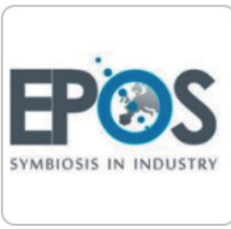

EPOS (Enhanced energy and resource Efficiency and Performance in process industry Operations via onsite cross-sectional Sumbiosis) [30]. Proiektua abian dago. EU industrien lehiakortasuna indartzea espero da energia kudeaketa hobetuz. Proiektuaren partaideak dira Ghent University, ArcelorMittal, CEMEX, INEOS, Omya UK, Veolia R\&I, EPFL, Belsim, Strane Innovation, Korona, eta Quantis.

Ildo berean, MAESTRI (total resource and energy efficiency management system for process industry) [31] proiektuan lan egiten ari da. Horretan, kudeaketa sistema bat garatu da industrien eraginkortasuna sustatzeko eta haren inplementazioa errazteko. Kudeaketa sistema horren bitartez baliabide eta energia kontsumoaren eraginkortasun eza identifikatuko dira eta balio gehigarriko hobekuntzen inplementazioan erabakiak hartzen lagunduko dute. Proiektuan kide dira ISQ, INEGI, ISMB, ATB, Fraunhofer FIT, University of Cambridge-Institute for Manufacturing, Lean Enterprise Institute Polska, SINERGIE, IZNAB, Microprocessador, MCG mind for metal, GLN Plast, J.W. Ostendorf, OAS eta Worlée. 
Naiara Romero-Anton, Koldobika Martin-Escudero, Luis Alfonso del-Portillo-Valdés

Industria sektorean, eraginkortasun energetikoak energiaren segurtasuna eta klima arintzea ekarriko ditu. Hala ere, kontuan izan behar dugu sektore horretan erabiltzen den energia beste gai askok eraginda dagoela, adibidez, garatuta dagoen teknologia, industria produkzio prozesuak, energia iturburuak, energiaren salerosketan ezarritako prezioak, eta eragin politikoek . Nahiz eta sektore horren energia erabilera konplexua izan, ekintza tekniko anitzak aurrera eraman behar dira eraginkortasun energetikoa industrian hobetu ahal izateko: berriztagarriak eta birziklagarriak diren materialak erabiltzea, ekipo edo erreminta zaharrak berrien ordez eguneratu eta ordezkatzea, bero eta hondar energia galerak murriztea, energia kudeaketa erabiltzea, prozesuen kontrola hobetzea, eta potentzia plantetan erabiltzen diren ekipamenduen diseinua optimizatzea. Ondorioz, gobernuak lau korrontetan lan egiten dihardu industriak energia eraginkortasuna hobetzera bultzatzeko: (1) Ekipoen eraginkortasuna definituz erregulazioak ezartzea, industrializazio prozesu eta konfigurazioen eraginkortasuna erregulatu eta energia kudeatzeko erregulazioa ere ezartzeko. (2) Zergak ezartzea, adibidez energia zergak, «cap and trade» eta energia motaren araberako prezioak bereiztea. (3) Gizartea sentikortzea hezkuntza eta trebakuntzaren aldetik, eta, azkenik, (4) Elkarte edo federazio industrialak sortzea. Azken horiek energia eraginkortasunerako aukerak eta neurketa kooperatiboetan lan egingo dute.

\section{ETORKIZUNEKO HELBURUAK}

Etorkizunari begira, EBko liderrek 2030 urterako ingurumen eta energia helburuak honako hauek izan beharko zutela adostu zuten $2014 \mathrm{ko}$ urrian:

- 1990. urteko mailarekin alderaturik, berotegi efektuko gasak \% 40 murriztea.

- Energia berriztagarrien parte hartze minimoak \% 27koa izan behar du.

- Eraginkortasun energetikoaren hobekuntza minimoak \% 27koa izan behar du.

- \% 15eko elektrizitate interkonexioa (adibidez, EBk sortutako elektrizitatearen $\% 15$ beste herrialdeetara garraia daiteke).

2020 eta 2030 helburuen arteko konparatiboa 4. irudian laburbiltzen da. 


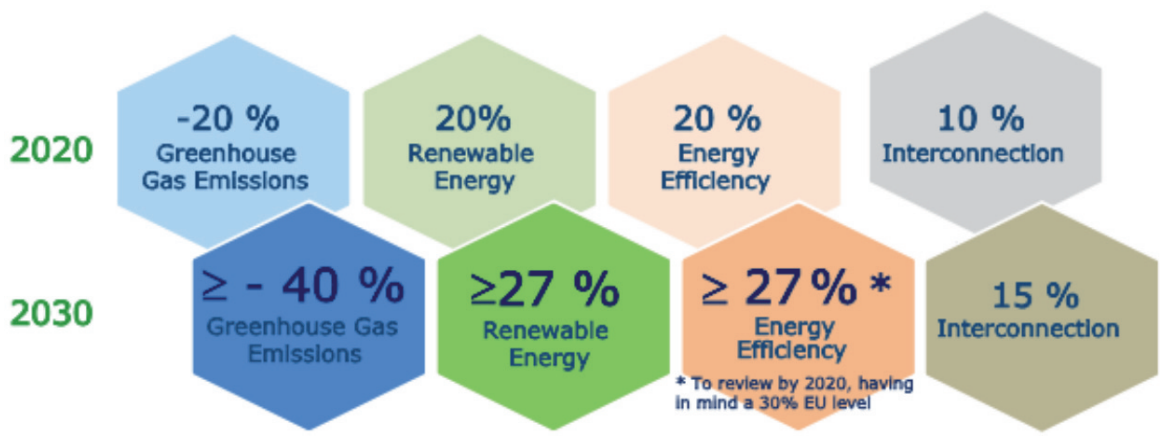

4. irudia. 2020 eta 2030 energia helburuak.

Proposatutako helburuak lortzeko, EES eguneratu beharko da, energiaren segurtasuna eta lehiakortasunarentzako adierazle berriak definitu beharko dira eta gobernantza ideia berriak proposatu behar dira. 2030eko Klima eta Energia pakete berria aukera ikaragarria da karbono baxurako industriak suposatzen den trantsizio energetikoa aurrera eramateko. Bestetik, EB «Horizon 2020» programa ordezkatuko duen «Horizon Europe» programan lan egiten ari da. «Horizon Europe» 2021-2027 urteetarako ikerketa eta garapen programa da eta 2030 xedeak lortzeko bide-orria izango da. Bestetik; epe luzera, Europako ekonomiak ingurumena errespetatzea nahi du EBk eta, horretarako, energia kontsumo txikiagoa ezinbestekoa da. Hori dela eta, 2050 urterako karbono baxuko ekonomia izatea bilatzen da; beraz 2050eko energia bide-orriak honako hau adierazten du:

- 1990. urteko mailarekin alderatua, berotegi efektuko gasak \% 80 murriztu behar dira.

Emisioak murrizteko potentzial handiena duen sektorea energia potentzia instalakuntzak dira. Ondorioz, potentzia ziklo instalakuntzetan gogor lan egitea beharrezkoa da. 2050erako potentzia instalakuntzen $\mathrm{CO}_{2}$ emisioak erabat desagertzea espero da; halaber, elektrizitateak erregai fosilak ordezkatuko ditu bai garraioan, bai beroketa sistemetan. Gainera, elektrizitatea energia berriztagarrietatik lortu nahi da, bai haize, eguzki, ur edo biomasatik, edo emisio baxuko beste teknologia batzuetatik ere, potentzia instalakuntzak karbono hartze eta biltegiratze teknologiaz hornituta. Aurretik esandakoa aplikatzen bada, berotegi gasen murrizketa posiblea 5. irudian erakusten da. 
Naiara Romero-Anton, Koldobika Martin-Escudero, Luis Alfonso del-Portillo-Valdés

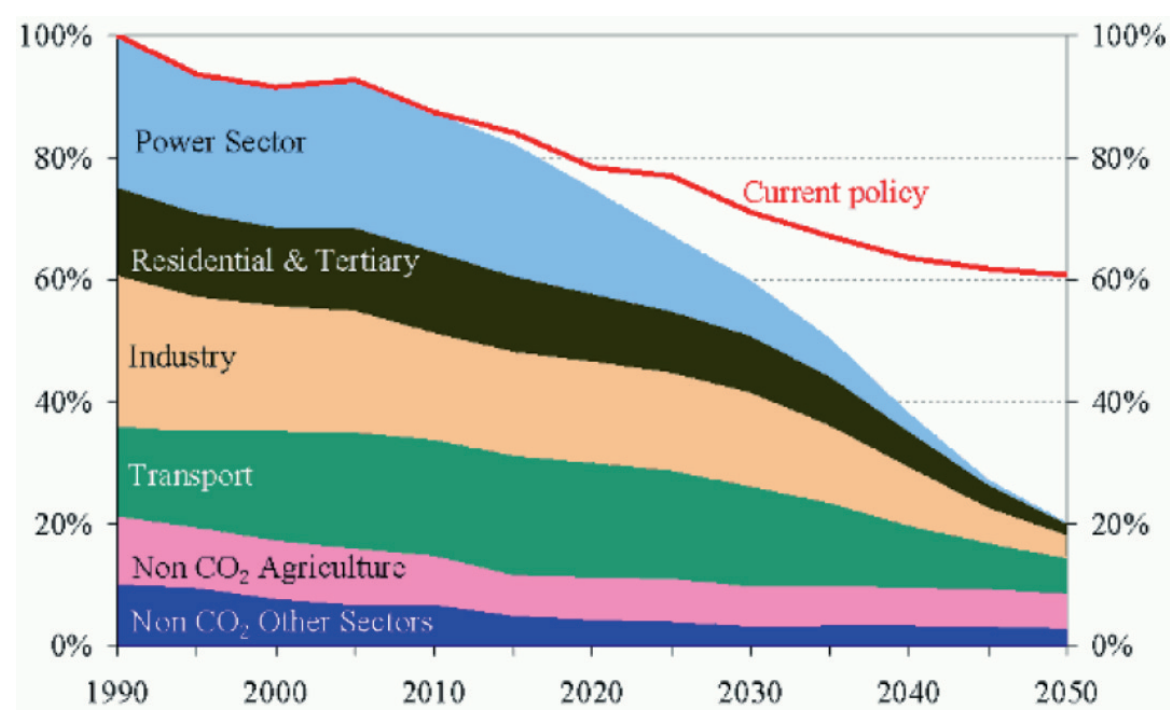

5. irudia. Berotegi gasen \% 80 murrizketa EB (\% 100 1990) [32].

EBk 2030 eta 2050 urteetarako deskribatutako erronkak beteko dituela ziurtatzeko, «Energia Batasun Paketea» [33] eratu du. Pakete horren helburu nagusia da gaur egun 28 herrialdez osatuta dagoen energia sistema EBko egitura bakar batean eraberritzea. Horretarako bost dimentsio deskribatzen ditu: (1) Energia hornikuntzaren segurtasuna izateko energia iturria anitzak behar dira, alboko herrialdeekin estu lan egin eta krisi garaian gasa erosiko duen erakunde arduradun bat izatea, (2) Emisioen murrizketa: 1990. urteko mailarekin alderaturik, 2030. urterako helburua berotegi gasak \% 40 murriztea da; beraz, ESS berrikusi behar da. Bestetik, EBk energia berriztagarrien liderra izan behar du, batez ere eguzki eta aire teknologietan, eta gainerako teknologia eta azpiegituretan inbertitzea sustatuko da. (3) Erabat integratutako barne merkatu bat izatea. (4) Eraginkortasun Energetikoa: energia kontsumoa gutxiagotzen bada, energiaren inportazioa eta poluzioa murriztuko da. (5) Ikerkuntza eta garapena karbono baxuko teknologietan [34]. Beraz, 2050 urterako lortu nahi diren xedeak lortzeko, «Barne Merkatuko 4. Energia Paketea» eratzea espero da. Horren bitartez, potentzia merkatua erreformatzea espero da, eta baita karbono baxuko teknologien politikak EB Energia-testuinguruan definitzea ere.

Laburbilduz, 2050. urteko helburuak lortzeko ikerkuntza lerroak dira: karbono baxuko teknologia, industrian, garraioan eta eraikuntzetan eraginkortasun energetikoa hobetzea, energia berriztagarrien erabilera sustatzea elektrizitatea ekoizteko, emisiorik gabeko garraioan apustu egitea, ordezko erregai fosilak edo errekuntza metodologia berriak erabiltzea emisioak mu- 
rrizteko (flameless combustion, hidrogenoa erregai moduan, egoera gainkritikoan gas diren erregaiak), karbono hartze eta biltegiratze teknologia potentzia instalakuntzetan aplikatu eta hiri ondarea murriztea.

\section{ONDORIOAK}

Gaur egun indarrean dauden zenbait direktibaren helburuak eta zergatiak azalduz, EBko energia testuingurua deskribatu da.

Testuinguru horretan, industria arloak, zentral termikoak zein petrokimikoak, eta bestek ingurumenean duten eragina eta kontsumitutako energiaren garrantzia aztertu da. Argi dago arlo horretan lan handia egin behar dela. Horrexegatik, tokian tokiko ikerkuntza anitz aurrera eramaten ari dira, besteak beste, teknologia eraginkorrenak aurkitzeko helburuz.

Hala ere, gizartearen erantzukizuna ezinbestekoa da, eguneroko bizitzan kontzientziarik gabe erabiltzen delako energia eta nork bere ahalegintxoa egin behar duela argi dago.

Azkenik, EBk etorkizunerako dituen helburuak aztertu dira, eta zaila egiten zaigu pentsatzea 32 urte igarota, elektrizitate kontsumo osoa energia berriztagarrietatik etorriko zaigula; EBk lortuko duela uste al duzue?

\section{BIBLIOGRAFIA}

[1] Regulation (EU) No 1291/2013 of the European Parliament and of the Council of 11 December 2013 establishing Horizon 2020-the Framework Programme for Research and Innovation (2014-2020).

[2] Directive 2009/28/EC of the European Parliament and of the Council of 23 April, 2009 on the promotion of the use of energy from renewable sources.

[3] Communication from the commission to the European Parliament, the Council, the European Economic and Social Committee and the Committee of the Regions -Energy Efficiency Plan 2011.

[4] Directive 2012/27/EU of the European Parliament and of the Council of 25 October 2012 on energy efficiency.

[5] Directive 2003/87/EC establishing a scheme for greenhouse gas emission allowance trading.

[6] Directive 2010/75/EU of the European Parliament and of the Council of 24 November 2010 on industrial emissions (integrated pollution prevention and control).

[7] Directive 2009/125/EC of the European Parliament and of the Council of 21 October 2009 establishing a framework for the setting of eco-design requirements for energy-related products. 
Naiara Romero-Anton, Koldobika Martin-Escudero, Luis Alfonso del-Portillo-Valdés

[8] Regulation (EC) No 663/2009 of the European Parliament and of the Council of 13 July 2009 establishing a programme to aid economic recovery by granting Community financial assistance to projects in the field of energy.

[9] Proposal for a DIRECTIVE OF THE EUROPEAN PARLIAMENT AND OF THE COUNCIL amending Directive 2012/27/EU on energy efficiency COM/2016/0761 final - 2016/0376 (COD)

[10] The coaliation for energy savings http://eedguidebook.energycoalition.eu/ index.html (accessed February 2018).

[11] BOE-A-2017-1066 Paris Agreement Ratification.

[12] Directive 2009/29/EC of the european parliament and of the council of 23 April 2009 amending Directive 2003/87/EC so as to improve and extend the greenhouse gas emission allowance trading scheme of the Community 2009/29/CE.

[13] Communication from the Commission to the Council, the European Parliament, the European Economic and Social Committee and the Committee of the Regions - A European strategic energy technology plan (SET-plan) 'Towards a low carbon future'.

[14] COMMUNICATION FROM THE COMMISSION Towards an Integrated Strategic Energy Technology (SET) Plan: Accelerating the European Energy System Transformation.

[15] MOLINA, G. (2012) 0 Gaia: ¿porqué la eficiencia energética es importante en la sociedad actual?. Argitaratu gabeko materiala.

[16] Council Regulation (Euratom) No 1314/2013 of 16 December 2013 on the Research and Training Programme of the European Atomic Energy Community (2014-2018) complementing the Horizon 2020 Framework Programme for Research and Innovation.

[17] European Institute of Innovation and Technology (EIT) https://eit.europa.eu/ (Accessed January 2018).

[18] Joint Research Centre (JRC) https://ec.europa.eu/jrc/en (Accessed January 2018).

[19] EUROSTAT. Final energy consumption by sector. http://ec.europa.eu/ eurostat (Accessed January 2018).

[20] Sustainable Process Industry through Resource and Energy Efficiency https://www.spire2030.eu (accessed January 2018).

[21] Leadership in Enabling and Industrial Technologies (LEIT). http://ec.europa. eu/programmes/horizon2020/en/h2020-section/leadership-enabling-andindustrial-technologies (accessed January 2018).

[22] Indus3Es. http://www.indus3es.eu/ (accessed December 2018).

[23] I-ThERM. http://www.itherm-project.eu/ (accessed December 2018).

[24] TASIO. http://www.tasio-h2020.eu/ (accessed December 2018).

[25] SusPIRE. http://suspire-h2020.eu/ (accessed December 2018).

[26] Smartrec. http://www.smartrec.eu/ (accessed December 2018).

[27] VULKANO. http://www.vulkano-h2020.eu/ (accessed December 2018).

[28] DREAM. https://www.spire2030.eu/dream (accessed December 2018). 
[29] IMPROOF. https://www.spire2030.eu/IMPROOF (accessed December 2018).

[30] EPOS. https://www.spire2030.eu/epos (accessed December 2018).

[31] MAESTRI. https://maestri-spire.eu/ (accessed December 2018).

[32] 2050 low-carbon economy. https://ec.europa.eu/clima/policies/ strategies/2050_es

[33] Communication from the Commission to the European Parliament, the Council, the European Economic and Social Committee, the Committee of the Regions and the European Investment Bank - A framework strategy for a resilient energy union with a forward-looking climate change policy (COM(2015) 80 final of 25 February 2015).

[34] NER 300 programme - increasing low-carbon technologies in the EU. 